A N N A L E S

UNIVER S T A T IS MARIAE CURIE-SKŁODOW S A LUBLIN - POLONIA

VOL. XXIX, 2

SECTIO J

2016

The Witelon State University of Applied Sciences in Legnica, Poland

\title{
NATALIIA POBIRCHENKO
}

pobirchenko_n@mail.ru

\section{The Author's School of the Ukrainian Academician Oleksandr Zakharenko}

Autorska szkoła ukraińskiego akademika Aleksandra Zacharenki

\begin{abstract}
The article is devoted to a well-known - in Ukraine and neighbouring countries - TheSchool on the Ros River and to its founder Oleksandr Zakharenko with his unique system of education. Zakharenko is characterized not only as an outstanding educationalist, but also as a sincere and modest person. The history of foundation and development of the Zakharenko's School has been given, and the role of the author's personal traits in this process has been explained. His pedagogical system, based on the triangle: parents - a child - a teacher, has been described and the importance of each of its elements has been justified.

The author shows the structure of the School and gives a description for each of five main educational centres: the Centre for Junior School, the Centre of Health, the Centre of Labour, the Centre of Culture and Education, and the Centre for Senior Students. The place of labour in the student's personality formation has also been described. The importance of the collective body has been mentioned as a means for solving the problem of a young person's socialization, and as a way to establish responsibility and skills of self-organization. It has been stressed, that even the best collectivism cannot substitute an individual work with a child. The individual approach based on assisting the child's work has been characterized.

The author draws attention to the system of assessment and encouragement. The latter is connected with providing successful students with grants, prizes and diplomas. The special place has been given to the system of moral incentives, consisting in telling the student's story on TV or in the newspaper. It has been marked that the idea of creativity, necessary during the learning, was the most important in Zakharenko's education system. The author emphasizes and justifies that the Zakharenko's School meets all main demands of a "school for self-realization" paradigm.
\end{abstract}


Key words: Oleksandr Zakharenko; School on the Ros River; the author's school; triangle: parents - a child - a teacher; individual work with a child; idea of creativity; "pedagogy of specific purpose"

\section{INTRODUCTION}

The outstanding School on the Ros River was created by Oleksandr Zakharenko. He is famous for his unique system of teaching and learning, and his name is well known in the pedagogical sphere in Ukraine, from the Academy of Pedagogical Sciences to rural schools.

To say more, the phenomenon of the School on the Ros River is studied, analyzed and used by scientists from Europe. "To consider the public opinion" does not mean to follow the fashion but to realize the true value of the talent creating ideas that live and work like eternal mechanisms of wisdom.

We have been living without Zakharenko for more than 10 years already, but his ideas are not extinguished, are not forgotten, it is quite just the opposite. Today his works seem to be even more valuable. His ideas are being studied, tested in new environments and put into practice. So, the effect of the approaching in time and expansion in space is observed for the ideas created in the village of Sahnivka. It is really true that "everything great is seen from afar".

Those who are interested in Zakharenko's idea and who did not have a chance to visit the School on the Ros River when its creator was alive, often ask: What kind of person Oleksandr Antonovych Zakharenko was? What was his secret, how was it possible to form such an extraordinary centre of culture, happiness, and creativity in the times when everyday life of a remote small village was oppressed by the ideological dictate?

\section{ZAKHARENKO AS A MAN, CITIZEN AND PEDAGOGUE}

I chanced to have been acquainted with Zakharenko and to have been working with him in the educational sphere for many years. Of course, it is impossible to characterize such a person in a few words. But I am sure that the understanding of his success, effectiveness and efficiency of his educational principles lies in his being sincere in communication with people. He did not have any traits of hypocrisy or duplicity. He was characterized as an ordinary and modest person having a lot of energy and talents. He wrote in his work Pieces of Advice for a Colleague Created on the Ros River: "Dear colleague! If you want your students to be modest, you should be modest yourself. And though it is said that modesty is out of fashion, it has been the main trait for a teacher profession for many years" (Zakharenko 2005, p. 4). He had never had divergence in words and actions, in 
life principles for himself and others. That is why one could not help believing him, and children realized it better than others.

There is a saying that "it is easier to be a prophet in the native country than in the native village". In the village everybody is seen easily, no action can be hidden and every word will be heard. Both old people and children in the small village of Sahnivka (Korsun-Shevchenkivskyi District, Cherkasy Region) liked Zakharenko, he had great authority with the community. But that was not owing to power, as he did not have any administrative or financial resources (he was just a headmaster of a rural school). Zakharenko was a real spiritual leader - "spiritual headmaster" as he was called in the village.

Zakharenko had a lot of different honours: Deputy in USSR Supreme Board, Honoured Teacher of Ukraine, a Head of Ukrainian Teachers' Creative Union, an academician, a member of Ukraine's Academy of Pedagogical Sciences, he was awarded the Best Worker in Education Title, by the Order of Lenin and Medal of Anton Makarenko, and he won many professional competitions.

Having such a long honour and recognition list (the given one is incomplete), Zakharenko, as a talented and competent pedagogue, had many opportunities to work in the capital city, to head a university chair and to have all conditions for his creative work. He could give up village routine, so necessary but requiring so much energy and time. Many times he was proposed high posts, even that of the Minister of Education of Ukraine. But Zakharenko refused all of them, giving a simple and laconic reason: "I will not leave the village of Sahnivka". The School on the Ros River was his work, the most important thing in his life. And among all honours the best was the status of the Author's school for his creation in the village (Ministry of Science and Education Decree dated February 1, 2002).

In the 1950s he came to Sahnivka village as a young teacher after graduating from the Cherkassy Pedagogical Institute. It was an ordinary rural school, poor and without perspectives, situated in a remote village. It is strange to say such words about the present Sahnivka village, but it is an indisputable fact that the village became popular all over the world due to the School.

They grew together - the young physics and mathematics teacher, the headmaster Zakharenko (since 1966), and his school.

\section{THE IDEA, EDUCATIONAL SYSTEM AND PRINCIPLES OF ZAKHARENKO'S SCHOOL}

One of the most important principles for Zakharenko's successful work was the base he had chosen for his education system. It did not rely on ideological postulates but on eternal human values: family (mother cult will be shown below), beauty of nature, charity, assiduity, love of the native land and the country. Zakharenko is said to create "pedagogy for a specific purpose" in Ukraine. 
His aim was to find a specific purpose which delights and unites the staff. Looking into all ideas of the talented pedagogue now, everybody can draw the following conclusion: the main purpose of his life was to create the school where the atmosphere of creativity, happiness, and confidence, inner, moral and physical health constantly dominated like fresh air in the field or at the seaside. In such an environment, children became healthy people with psychological strength and immunity for the whole life.

It is worth saying that Zakharenko never followed hothouse conditions, isolation from ordeal, troubles and dirtiness which our modern world is full of.

In their alma mater the schoolchildren from Sahnivka village received moral health, ability to appreciate good and impartial things and actions, confidence of their strengths and those qualities helped them to resist life difficulties.

Zakharenko's pedagogical system forms a triangle: parents - a child a teacher. The development of harmonious relations in the triangle middle - mutual respect, constant collaboration - is one of the most important factors necessary for creating the atmosphere where a child's positive abilities and skills can be developed.

Studying Zakharenko's published works one can see that he avoided formal expressions like "to determine the task", "to organize an event", etc. He used to call principles of his education system as ideas. On the walls of school hall, in Sahnivka village, there is an idea considered to be fundamental, determinative, great, simple and stated in the words understood by every child: "If you want to change the world for better, to save its original beauty, untouched holiness, you should begin with yourself!". So, let's cross the threshold and enter the author's school of the well-known Ukrainian pedagogue.

The school is divided into five main educational centres. The Centre for Junior School occupies one section of the sports building. There are classrooms, recreation rooms, computer complex, and the room of tales. Rooms for choreography lessons, a music showroom, and a branch office of art school are situated nearby.

The Centre of Health, Sport and Recreation consists of a gymnasium, a swimming-pool, and volleyball and basketball sports grounds. There is also a shooting range and sports ground for gymnastics lessons. Here one can find phyto bar where medicinal prophylactic teas are made, and some of them are original teas brewed according to recipes of Sahnivka villagers.

The Centre of Labour training and education has seven workshops: turners, metalworkers, woodworker's, culinary, tool-making, and electrical engineering. Besides, there are hothouses, a school field, experimental areas, fleet of motor vehicles in miniature.

The Centre of Culture and Education has a separate building including a wellarranged museum called "My Little Motherland", a room for lectures and film watching, exhibition hall, observatory and planetarium. Besides, the school area 
has the Place of Memory, the Well of Conscience, the Fountain "Wheat Ear", the Pole of Peace, monuments to Taras Shevchenko (a Ukrainian great poet), Olya Lysenko's nook (a popular artist). All these things create a special atmosphere of the intellectual wealth at school.

The Centre for Senior Students is situated in the oldest and the biggest school building. It is the main education base: classrooms of chemistry, physics, mathematics, computer science, biology, Ukrainian and foreign languages and literature. The same building combines a pedagogical reception room, a library with reading rooms, the room of wisdom and beauty, radio and broadcasting studio, and a canteen.

The School in Sahnivka village can be compared to a small country having its own peculiarities. And if, for example, experimental fields and a gymnasium can be found everywhere, are there a lot of Ukrainian rural schools having observatory and own television channel covering 15 villages? All these things appeared gradually in Sahnivka village, year by year. The headmaster had an idea and it was transformed into specific actions. That was the idea of bringing up a healthy child (this idea belongs to the main ones in Zakharenko's pedagogical system - Oleksandr Antonovych put it into practice: he began to build not just a gymnasium - it sounds too ordinary - but the Building of Health with a swimming pool). It cost a lot of effort to embody such an idea in the village in the1980s when even bricks were hard to buy. It was the construction built by teachers, parents and students. And there is a gymnasium now, since 1983 it has been functioning with summer and winter swimming pools. On the experimental fields, one can find a great special bed called "Green pharmacy", which is divided into sections where herbs are grown. The plants are cultivated according to all pharmacology principles. There are strict pieces of advice: how to grow, when to gather, to dry, and what every herb is for. Every autumn, the students store up medicinal prophylactic tea "The bouquet from Nadlissya (wooded districts of Ukraine)" and make special preparations for the drink "Shepherdess" (local original recipe). Here is the chain combining three links: idea - specific aim - consecutive actions. And the result of the idea's realization is children's strong health. Practically every school child attends the swimming pool once or twice a week. The water is treated with silver and rich in salt from the Black Sea. As a result, it has medicinal properties. According to doctors' conclusions, children having scoliosis stabilize their health state owing to lessons in the swimming pool during one season. The school curriculum in Sahnivka village contains compulsory credits in swimming, school leavers take swimming examinations and the grades are included into a school leaving certificate.

To protect habits of work and to make a child respect labour are the tasks for every teacher. There is a specific approach to labour in Zakharenko's School system. If you simply give children brooms and spades and order to sweep and to dig, the result can be opposite to the expected. Mechanical execution of dull 
operations may create boredom and compulsion may result in protest. Zakharenko's rule is that a child's even simple work should include creativity, game, romantic and inventive components (Zakharenko 1997, p. 26). For example, school children from Sahnivka village work in forestry - they store up hay and brushwood for feeding forest habitants in winter. The students are divided into groups and every group is headed by elected leaders and instructors - a class teacher or a parent.

The School makes small parts for agricultural machines for KorsunShevchenkivskyi Machinery Plant, and sews gauntlets, overalls, aprons for the Korsunchanka Factory. For children, work with a purpose, which requires some skills and abilities, is more interesting. In the fifth form children receive work records to register the work done.

Children's work, especially when some skills are needed for complicated operations, as Zakharenko put it, is a constant complex of brain efforts, combination of a child's thoughts, interests, needs and feelings arising during this process.

The main matter is intellectual effort, conscious creativity, and development of self-esteem. Zakharenko wrote: "The feeling of respect for people's work, material welfare and spiritual values created by people is cultivated when students see things made by themselves and others, which protects and improves them. If students do not like to see dust and mess around, if they are concerned about cleanness, order, beauty everywhere, they enjoy working and realize the cost of creating welfare" (Zakharenko and Mazuryk 1979, p. 98).

The specific aim at the School has been and still is today its precept: "To strengthen labour worship in children's consciousness". There are some quotations from the School Working Plan of the last years: "To make students realize such main principles: people can develop only if they are hard-working and industrious. Talent and a gift, beauty and strength, great wisdom and strong will, spiritual values and labour honour - they are the result of creative daring and hard work. Do not waste time, work and develop every day (...). Respect hard-working people. Love and appreciate any work if it brings welfare and happiness to others. There are different kinds of work: manual and intellectual, easy and hard, interesting and dull, for you and for people, for today and for future, for parents and for the state. Enjoy any work, find happiness and achieve success" (Zakharenko and Mazuryk 1979, p. 120).

The problems of young people's adaptation in the society, searching for their own position, determination of a social role optimal for a certain character are of great importance at the School in Sahnivka village. The system of self-control was established at the School. It is the best way to develop initiative, relaxedness, to establish responsibility, practical skills of self-organization. A classical model by 
A. Makarenko with its rules, system of rights, duties, and self-management was taken as a pattern. The senior student on duty is appointed to a deputy of the headmaster; he is to organize the school life. He has keys from the School, has the right to give orders (students have to follow them), to make remarks and to express his gratitude. The headmaster's young deputy is to form a detachment on duty which works during a week and keeps order at the School.

The environment, collective body forms an individual - this statement is very typical of the School on the Ros River, where a lot of outstanding people have grown in the creative and lively atmosphere. But even the best collectivism cannot substitute an individual work with a child. And thus, children should be in the centre of teachers' attention, their contemplations and observation. There is a special form of characteristics at the School in Sahnivka village. The front page includes "a student's psychological characteristics": his traits, temperament, abilities, interests, and his position among the group of classmates. A child's family conditions are briefly described on the second page. The class teachers write here observation results taken from their diaries once a term.

The conception of individual work with a child is based on a traditional principle: to help a child have success in certain things they do. Irrespective of their studying progress children should do things they are interested and successful in, this will help them in self-realization. A child's indifference can be depressed only by striving for success in a chosen thing.

The School in Sahnivka village has its own report cards which can reflect students' studying and progress well. The academic year starts and students write in the special column the grades they are planning to receive during the next term. A report card includes grade columns for assiduity, industriousness, good breeding, treatment of relatives, civic duties, etc. At the end of each term real grades are taken. The grade indices are discussed both by teachers and classmates. Such a report card is the best way to see a student's progress and his or her position among classmates, and, at the same time, it is a stimulus for developing. "A report card may show not only the student's personality but also the reasons why he or she is like this" - Zakharenko wrote.

The main aim of the School in Sahnivka village is to help a child find his or her own way in life. And it is the School of self-determination with the motto: "A child's heart can be captured only with inspiration of creativity, work and studying".

Speaking about report cards and grades one may think that such a democratic approach is excessive. But democracy is one of the basic principles in the Author's School functioning. It does not mean the lack of any restraint but the high level of self-responsibility. Every student is to study according to his or her intelligence 
level, to be aware of his or her abilities and skills and to receive definite marks. If a senior student agrees, the mark is put into the register; the school rules provide students with rights to tell the topic again and to attend extra evening consultation.

In senior school the system of assessment shows specific results but its basic principles are formed in a preparatory school where characters are diagnosed and precedence is established.

Speaking about democracy in assessment, one may say that at the School of Sahnivka village the grade results of a term are not put subjectively. Every mark is taken and based on 10 grades analysis (such method was popular at the School in Sahnivka village when 12-grade-scale was not even thought about in Ukraine). If there are less than 10 marks and truancy, skipped topics are obvious; a pupil will not be assessed or will have a poor mark. It means that he or she missed the opportunity to get a good grade. And the previous excellent marks will be of no help. In such situations any compromises are not expected by the school rules.

The system of incentives is also worth mentioning. It provides grants for excellent students and for studying specific subjects, prizes for activity in school business, diplomas for success in different competitions, even prizes for everyday morning exercises (famous roll-calls in Sahnivka village). School has its own system of moral stimulation: reports about a student, his or her family are often broadcast on the school or a local TV. The usage of incentives is strictly regulated and has its rules because it is very important to keep within limits, not to be formal, otherwise the system loses its effectiveness.

The basic idea in Zakharenko's education system was creativity, creative education: to learn not with enforcement, but with a child's aroused interest. This classical principle was transformed by Oleksandr Antonovych. Every teachers should use the game. The game that trains is a very serious but exciting work. Every day, at the morning roll-call, an intellectual competition is played. The school atmosphere is rich in romance, humour and music. Daily jogtrot is not felt even on an autumn day. And children in this bright comfortable School are not simple consumers but also the creators and participants of the process.

Competitions dedicated to the best form, the nicest field spot, the brightest flower bed take place here. According to Zakharenko's principles, every square centimetre of the wall in the yard or the school ground should have emotional colour in order to be educative. A good tradition was begun - every pupil plants a tree: during the last years a grove has grown - more than a thousand trees. Every form has their own arborvitaes providing fresh air for young children, flower beds, nooks for rest and it provides with competition, a space for creativity. To say more, in the greenhouses the flower sprouts are grown by children themselves, both for school flower beds and for village inhabitants' ones (last year 10 thousands sages were only planted). 
The idea of emotional education, memory awakening was the first one introduced in the Zakharenko's School. The main task was to establish a museum where the letters of war soldiers were main things to be displayed. Once Oleksandr Antonovych said that studying education experience in Poland, he met Polish school children who could recollect their family tree up to the eighth generation. Unfortunately, such a tradition has been lost in our country but it is appreciated. The specific realization of the idea is formation of the book Encyclopaedia of the School Generation (four volumes have already been written) - a unique issue in the history of Ukrainian pedagogy.

\section{THE ROLE OF TEACHERS AND PARENTS}

The Zakharenko's School is not only for children but also for teachers and parents. True teachers were formed from young people who came to the School after graduation. Despite Zakharenko's numerous demands, they left the School very seldom. Oleksandr Antonovych used to emphasize that special selection of staff was necessary for an elementary school. It is hard to overestimate the role of the first teacher: in his or her hands there is a child's future and the state future. That is why teachers for a primary school should be selected beginning from pedagogical classes, colleges, universities. They must be the gifted people with creative streak, having a great desire to teach young school children (Zakharenko 1997, p. 16). In Sahnivka village the best and the most experienced teachers work in an elementary school. There is an excellent rule: a teacher gives two demonstration lessons a month to be discussed. It is an effective process so as to create together, to gain new experience and to see the colleagues' outcomes. "One more riddle in a teacher's creativity", wrote Zakharenko, "is in his or her absolute freedom in choice of methods and forms. He or she can't work without it. There is only one demand - knowledge can be thorough when itis based on doubts and arguments, the student's own opinion and a research" (Zakharenko 1997, p. 4).

As A. Makarenko put it, the "pedagogical staff" is a synonym to the definition of the "school community" which means the partnership of teachers and students. This principle was followed by Zakharenko. Cooperation, mutual respect between the teachers and the students are those bases the personnel continue to follow after Zakharenko's death.

Let us mention the third part of Zakharenko's educative triangle - parents. Parents are constant participants of all school events; even grandparents often take part in them. For example, they built all the buildings on the school territory in Zakharenko's period. Sometimes the School in Sahnivka village is called the "school built by work team". Parents also participate in the school exhibitions and celebrations; from time to time they are present at school examinations, and make reports in the school radio programmes. The University for Parents is functioning 
at the School. The experience of family education is generalized with the help of artistically pedagogical form for parents' work, relationships in family, community position being enlightened in the correct way. Proper emotions are aimed at increasing adults' interest in what is the most important to make a child be proud of his or her family. The parents together with children create their family tree, note important events from their family life. This information is a good basis for the Encyclopaedia of the School Generation.

Another basic idea in Zakharenko's school system is the cult of a mother. At the beginning of school course a series of discussions are prepared for the students. They are about treatment of a mother, a family, a lifelong responsibility for the mother. The plans and methodical synopses of such discussions are the school achievement and are kept at the School.

The image of the mother is regularly mentioned, children are offered to think who the mother is in a person's life, and in theirs too. In such a way thoughts of school children get more intensified, and their responsibility is realized. Zakharenko kept emphasizing: a pedagogue must consciously use the smallest opportunity - in the classroom, in extracurricular activity, when going for a walk, on the field ground, in the swimming pool or any other place - to remind children that everything good they have got, they got from their mothers. Before the $8^{\text {th }}$ of March there is the school tradition to celebrate a week devoted to mothers, grandmothers, schoolmistress and girls. Traditionally, it begins with the lesson of ethics in every form. During one of such lessons children themselves determined the principles:

- everyone's main duty is to love and respect the mother;

- everyone should do one's best to make the mother proud of her child, sure of his or her future;

- everyone should work in order to help the mother;

- everyone should obey the mother for her not to worry.

"Cultivating moral, emotional treatment of parents and relatives in children provides constant many-sided work", wrote Zakharenko (1997, p. 4).

\section{CONCLUSIONS}

It is worth emphasizing that the Author's School meets all main demands of the "school for self-realization" paradigm because: first, paradigm dominants are changed from socially- to humanistically-oriented, individuality is considered to be of great value and the main aim is a thorough development; second, the education process is controlled by the teacher and includes the opportunity to choose the activity according to interests; third, the child who is a participant of such a process acquires social experience - knowledge, abilities and skills of communication; and fourth, the teacher as a leader of education process, is both a highly qualified specialist and a friend, an advisor in collaboration with a student. 
The management model of the Author's School is complex, multi-component and, at the same time, highly effective, flexible and open.

Up to his last days Zakharenko worked hard to determine the strategic ideas for the school, development of the teachers' creative potential, to form innovative culture for his School. The Author's School provides self-realization of creative inclinations for both the students and the teachers - the creator was striving for it. Sahnivka village became a "pedagogical Mecca" for Ukrainian researchers and practical scientists and for foreign colleagues too. The strong organism of the establishment has been functioning without their spiritual headmaster for more than ten years. It means that the chosen strategy was right.

The colleagues often felt sorry for the fact that Zakharenko being busy with practice work and constantly surrounded by people did not write much. His first book The School on the Ros River was written in 1979, the next one Hurry Up To Make Good - almost 20 years after that, in 1997. Being terminally ill he wrote intensively in order to leave his thoughts on a paper. During his last years, in 2001 four volumes of the Encyclopedia of School Life were published and he called this work "a collective creation of the whole Sahnivka village". In 2002, his Pieces of Advice for a Colleague Created on the Ros River were issued. This work is a pedagogical precept of a great teacher where every thought is valuable. In the same year, shortly after Oleksandr Antonovych's death, a collection the 210 School Roll-Calls written in co-authorship with his son, Serhiy, was printed. Being small in scope, it is an extremely profound published heritage. It is like a deep methodological source for teachers to use. It is for researchers to analyse and generalize. It is for Zakharenko's ideas to be used in a new way.

\section{ROMANISED REFERENCES}

Zakharenko, O.A., Mazuryk, S.M., Shkola nad Rossyu, Kyiv 1979.

Zakharenko, O., Poradykolezi, narodzheni v shkoli nad Rossyu, Cherkasy 2005.

Zakharenko, O., Pospishaymo robyty dobro, Cherkasy 1997.

\section{STRESZCZENIE}

Artykuł poświęcony jest dobrze znanej na całej Ukrainie i krajach sąsiednich „Szkole nad Rosią" i jej założycielowi Aleksandrowi Zacharence z jego unikalnym systemem edukacji. Zacharchenkę określa się nie tylko jako wybitnego nauczyciela, ale też jako szczerego i skromnego człowieka. W prezentowanej pracy przedstawiono historię założenia i rozwój jego szkoły autorskiej oraz wyjaśniono rolę cech osobowych Zacharenki w tym procesie. Artykuł opisuje system edukacyjny, który opiera się na trójkącie: rodzice - dziecko - nauczyciel wraz z uzasadnieniem znaczenia każdego elementu i sposobu ich interakcji z innymi. 
Autor pokazuje strukturę szkoły i opisuje każdy z pięciu jej głównych ośrodków edukacyjnych: Centrum Szkoły Podstawowej, Centrum Zdrowia, Centrum Pracy, Centrum Kultury i Edukacji oraz Centrum dla Uczniów Starszych (liceum). Ponadto artykuł opisuje rolę pracy w kształtowaniu osobowości ucznia. Przypomniano w nim także ważną rolę zespołu jako narzędzia rozwiązania problemów adaptacji młodego człowieka w społeczeństwie, a także metody wpajania nawyków odpowiedzialności i samoorganizacji. Zauważono jednak, że nawet najlepiej zorganizowany kolektywizm nie zastąpi indywidualnej pracy z dzieckiem. Podano zatem charakterystykę koncepcji pracy indywidualnej, która opiera się na pomocy dziecku w samookreśleniu się w konkretnej sytuacji. Zwrócono również uwagę na system ocen i zachęt. Ten ostatni przewiduje stypendia dla najlepszych oraz nagrody za sukcesy w nauce.

Szczególną uwagę poświęcono systemowi zachęt moralnych, który znajduje odzwierciedlenie w opowiadaniu o uczniu w telewizji lub gazecie. Wskazuje się, że decydującą w systemie edukacji Zacharenki zawsze była idea kreatywności i twórczego uczenia się, która przeczyła edukacji pod przymusem. Autor uzasadnia też swój pogląd, że autorska szkoła Zacharenki spełnia podstawowe wymagania technologii paradygmatu „szkoły samorealizacji”.

Słowa kluczowe: Aleksander Zacharenko; ,Szkoła nad Rosią”; szkoła autorska; trójkąt: rodzice - dziecko - nauczyciel; praca indywidualna z dzieckiem; twórcze uczenie się; ,pedagogika konkretnego celu" 